\title{
Dinâmica de rizóbios em solo do cerrado de Roraima durante o período de estiagem
}

\author{
Jerri Édson ZILLI ${ }^{1}$, Gilmara Maria Duarte PEREIRA², Izaias FRANÇA JÚNIOR², Krisle da SILVA, \\ Mariangela HUNGRIA ${ }^{4}$, Janaina Ribeiro Costa ROUWS ${ }^{1}$
}

RESUMO

A fixação biológica de nitrogênio que ocorre em leguminosas é realizada por um grupo de bactérias conhecidas como rizóbios. A sobrevivência destas bactérias no solo é influenciada por diversos fatores como a temperatura, umidade e fertilidade do solo. O objetivo deste trabalho foi avaliar a dinâmica da população de rizóbios em solo após o cultivo de soja, durante o período de estiagem no cerrado de Roraima. Foram amostradas três áreas: i) cerrado nativo como referência; ii) área cultivada uma vez com soja inoculada com rizóbio; iii) e área cultivada duas vezes com soja inoculada com rizóbio em anos consecutivos. $\mathrm{O}$ solo foi coletado na profundidade de $0-10 \mathrm{~cm}$ em cinco períodos a partir do inicio da estiagem no mês de setembro de 2006 coincidindo com a época de colheita da soja e prolongando-se até março de 2007 (0, 45, 90, 135 e 180 dias). A população de rizóbios no solo foi avaliada pela técnica do número mais provável (NMP) utilizando plantas de soja e de feijão-caupi como espécies isca. Foi observado que na área nativa praticamente não existiam bactérias nodulantes de soja, mas havia uma população capaz de nodular o feijão-caupi de até algumas centenas de rizóbios por gramas de solo. O cultivo da soja utilizando sementes inoculadas elevou a população de rizóbios no solo que foi constatada por ambas às espécies de plantas isca. Nas áreas cultivadas, constatou-se uma intensa reduçáo da populaçáo de rizóbios no solo, em especial logo após a colheita da soja, continuando o decréscimo até o último período de avaliação. Conclui-se que o cultivo da soja inoculada com rizóbio eleva a densidade de rizóbios em solo do cerrado, mas durante a estiagem ocorre uma drástica redução dessa população, que pode chegar a mais de $99 \%$ considerando o início e final do período.

PALAVRAS-CHAVE: Glycine max; Vigna unguiculata; nodulação; número mais provável.

\section{Dynamic of rhizobia in the soil during the dry season in cerrado of Roraima}

\begin{abstract}
The biological nitrogen fixation in legumes is performed by a group of bacteria known as rhizobia. The survival of these bacteria in soils is affected by several factors, such as temperature, drought and soil fertility. This study was performed to evaluate the dynamics of rhizobia in the soil after soybean cultivation and during a dry season in the cerrado of Roraima. Three areas were sampled: i) native cerrado as reference; ii) an area previously cultivated with soybean for one season; and iii) another one cultivated for two seasons also with soybean. The soil was sampled at a depth of $0-10 \mathrm{~cm}$ in five times $(0,45,90,135$ and 180 days) during the dry season (September 2006 to March 2007). The rhizobial density in the soil was evaluated by the most probable number method with infection of soybean and cowpea plants. It was observed very low number of soybean nodulating bacteria in the reference area, but a high density, of up to several hundred rhizobia capable to nodulate cowpea was measured in this same area. Cropping of soybean with inoculated seeds increased rhizobial density evaluated by both trapping hosts. In cropped areas, an intense reduction of rhizobium density was observed just after soybean harvest, and this reduction continued until the end of the period of evaluation. It was concluded that soybean cultivation increases the density of rhizobial in the cerrado soil; however, this density is drastically reduced, during the dry season, by $99 \%$ at the end of the dry period.
\end{abstract}

KEYWORDS: Glycine max; Vigna unguiculata; nodulation; most probable number.

\footnotetext{
1 Embrapa Agrobiologia. Rodovia BR 465, km 7, Seropédica - RJ, CEP: 23890-000. Fone: (21) 3441-1500 - Fax: (21) 2682-1230. E-mail: jerri.zilli@embrapa.br; janaina.rouws@embrapa.br

2 Universidade Federal de Roraima - UFRR. Av. Ene Garcez, 2413, Boa Vista - RR, CEP: 69304-000. E-mail: gmdpereira@hotmail.com; izafrajunior@yahoo.com.br

3 Embrapa Roraima. Rodovia BR 174, km 8, Boa Vista - RR, CEP: 69301-970. E-mail: krisle.silva@embrapa.br

${ }^{4}$ Embrapa Soja. Rod. Carlos João Strass - Distrito de Warta, Londrina- PR, CEP 86001-970. E-mail: mariangela.hungria@embrapa.br
} 


\section{INTRODUÇÃO}

A fixação biológica de nitrogênio (FBN) realizada por bactérias formadoras de nódulos nas raízes de plantas pertencentes à família das leguminosas, conhecidas coletivamente como rizóbios, é afetada por diversos fatores edafoclimáticos (Zahran 1999; Sadowsky 2005). Entre estes fatores, a umidade do solo representa uma das maiores limitaçóes em regióes tropicais, onde a escassez de chuvas pode ocorrer associada com altas temperaturas (Hungria e Vargas 2000).

De forma geral, o solo é considerado sob déficit hídrico quando os teores de umidade estáo abaixo de $50 \%$ da capacidade de campo sendo comum nessa condição o aparecimento de efeitos negativos ao processo de FBN (Chalk et al. 2010). Os longos períodos de estiagem, com potencial hídrico do solo abaixo de -0,5 MPa representam uma condição que tende a reduzir a densidade populacional de rizóbios no solo (Hungria e Vargas 2000; Sadowsky 2005); embora algumas estirpes sejam capazes de sobreviver mesmo em condiçôes áridas (Waldon et al. 1989). A escassez de água provoca reduçáo na abundância de microrganismos porque, além de fazer parte da estrutura celular, é indispensável à maioria das reaçóes do solo, como a produção primária de energia, a decomposição da matéria orgânica, a liberação de nutrientes, o crescimento vegetal e a exsudação radicular (Sadowsky 2005).

Alguns estudos têm sido conduzidos para avaliar o impacto do déficit hídrico sobre a FBN, tanto em soja [Glycine max (L.) Merrill], quanto em feijão-caupi [Vigna uniguiculata (L.) Walp] (Serraj e Sinclair 1998; Figueiredo et al. 1999; Streeter 2003). Entretanto, existem poucas informaçôes sobre a sobrevivência dos rizóbios em solos cultivados com soja em condiçôes de estiagem prolongada, característica edafoclimática marcante no cerrado do estado de Roraima.

O cerrado de Roraima, segundo a classificação de Köppen, apresenta clima tipo Aw tropical chuvoso (Barbosa 1997), com precipitação média anual de aproximadamente 1800 $\mathrm{mm}$ e concentração de mais de $80 \%$ das chuvas entre os meses de abril e setembro e estiagem de até 120 dias (Mourão et al. 2006). Aliado a isto, o solo da regiáo apresenta baixa capacidade natural de retençáo de água devido aos baixos teores de matéria orgânica - frequentemente inferiores a 10 $\mathrm{g} \mathrm{kg}^{-1}$ - e textura arenosa a franco-arenosa. Estas condiçōes caracterizam um déficit hídrico no solo que pode reduzir drasticamente a densidade de rizóbios.

A quantificação da população de rizóbios no solo constitui uma informação útil, haja vista que define a necessidade ou não de inoculaçấo das leguminosas, quando estas forem reintroduzidas em uma mesma área. Além disso, o conhecimento da dinâmica de rizóbio no solo pode ser utilizado estrategicamente para melhorar o desempenho de inoculantes. Por exemplo, Martins et al. (2003), verificaram aumento da resposta da inoculação do feijão-caupi após longo período de estiagem, isto porque a estiagem havia reduzido a população de bactérias estabelecida no solo. Nestas condiçốes, portanto, o conhecimento da dinâmica da população de rizóbio no solo permitiu aumentar a competitividade da estirpe inoculante frente à população estabelecida no solo.

Neste estudo, para avaliar a dinâmica de bactérias nodulantes presentes no solo durante o período de estiagem foram realizadas amostragens em uma área de referência, uma área cultivada uma vez com soja inoculada com rizóbio e outra área cultivada duas vezes com soja inoculada com rizóbio em anos consecutivos, utilizando-se como espécies isca a soja e o feijão-caupi. Esta estratégia foi adotada, pois diferentemente da cultura da soja, o feijão-caupi possui maior capacidade de nodulação quando associado com bactérias nativas de solos brasileiros (Zilli et al. 2009) e o histórico de cultivo do solo interfere na densidade de rizóbio (Ferreira et al. 2000).

O objetivo deste trabalho foi avaliar a dinâmica da população de rizóbios presentes em solos de Cerrado de Roraima após o cultivo de soja e durante o período de estiagem.

\section{MATERIAL E MÉTODOS}

As amostragens do solo foram realizadas no Campo Experimental Água Boa da Embrapa Roraima, localizado no município de Boa Vista, Roraima (02¹5’00”N, 60³9'54”W). As amostragens foram realizadas em três condiçóes: i) uma área de cerrado nativo apenas com a presença de vegetação espontânea, como referência; ii) uma área aberta para o plantio em 2005 com correçáo do solo com cerca de $1500 \mathrm{~kg} \mathrm{ha}^{-1} \mathrm{de}$ calcário dolomítico (poder relativo de neutralização de $85 \%$ ), $500 \mathrm{~kg} \mathrm{ha}^{-1}$ de superfosfato simples e $50 \mathrm{~kg} \mathrm{ha}^{-1}$ de adubo formulado contendo micronutrientes (FTE BR-12) e, que havia recebido um único cultivo de soja em 2006 ( $1^{\circ}$ cultivo); e iii) uma área também preparada em 2005 , mas com cultivo de soja nas safras de 2005 e 2006 ( $2^{\circ}$ cultivo). Em todos os cultivos, as sementes de soja foram inoculadas com estirpes de Bradyrhizobium spp. indicadas para a cultura na proporção de 1,2 milháo de células por semente e durante o período de estiagem todas as áreas permaneceram apenas com vegetação espontânea. Todas as áreas apresentavam a mesma declividade e eram distanciadas umas das outras em aproximadamente 100 $\mathrm{m}$. Foram realizadas amostragens de solo para análise química e física e, na sede do campo experimental, situado a cerca de $600 \mathrm{~m}$ de distância da área de estudo, coletou-se diariamente a precipitaçáo pluvial com um pluviômetro de campo.

Para as amostragens, cada área foi definida com dimensóes aproximadas de $60 \mathrm{~m}$ x $100 \mathrm{~m}$ e, cada uma, foi dividida em três 
talhóes com largura aproximada de $20 \mathrm{~m}$, considerando-se cada talhão um bloco. Em cada bloco coletou-se uma amostra de solo composta por dez amostras simples retiradas a cada $10 \mathrm{~m}$, aproximadamente, no sentido da maior dimensão. As amostras simples foram retiradas na profundidade de $0-10 \mathrm{~cm}$ com o auxílio de um trado tipo holandês, o qual foi desinfestado com etanol 95\% antes das tradagens em cada bloco e área. Uma vez coletadas, as amostras foram transportadas imediatamente na temperatura ambiente e abrigadas da luz para o laboratório de Microbiologia do Solo da Embrapa Roraima, quando foram processadas no máximo 48 h após a coleta. Foram realizadas cinco amostragens de solo ao longo de sete meses, iniciando-se no dia 15 de setembro de 2006 -cerca de uma semana após a colheita da soja e coincidindo com o início do período de estiagem-e repetindo-se a cada 45 dias até o mês de março de 2007. Desta forma, os períodos amostrados compreenderam $0,45,90,135$ e 180 dias.

A determinação da população de rizóbio no solo foi realizada pelo método do número mais provável (NMP) com infecção em plantas de soja (cv BRS Tracajá) e feijão-caupi (BRS Mazagáo), as quais foram cultivadas em vasos de Leonard com substrato de areia: vermiculita $(2: 1)$ esterilizado em autoclave. Antes do plantio, as sementes foram desinfestadas pela imersão em etanol $70 \%$ por dois minutos, peróxido de hidrogênio $10 \%$ por cinco minutos e lavadas 10 vezes com água destilada esterilizada. Foram semeadas três sementes por vaso, deixando-se apenas uma planta após o desbaste realizado por ocasiáo da emergência. Os vasos, em triplicata, foram mantidos em câmara de crescimento com temperatura e umidade relativa do ar de aproximadamente $28{ }^{\circ} \mathrm{C}$ e $65 \%$, respectivamente.

O inóculo foi preparado de acordo com Andrade e Hamakawa (1994), partindo-se da retirada de fragmentos de material orgânico, seguindo peneiramento com malha de 4 $\mathrm{mm}$, diluição em solução salina $\left(85 \mathrm{~g} \mathrm{~L}^{-1}\right.$ de $\mathrm{NaCl}$ em água destilada) e sucessivas diluições até a obtenção da diluição $10^{-7}$, da qual, juntamente com as diluições $10^{-4}, 10^{-5}$ e $10^{-6}$, foram tomadas alíquotas de $1 \mathrm{~mL}$ que foram inoculadas nas plântulas de soja e feijão-caupi logo após o desbaste. Semanalmente cada vaso recebeu $300 \mathrm{~mL}$ da solução nutritiva de Norris (Andrade e Hamakawa 1994).

As coletas das plantas foram realizadas aos 25 dias após a emergência, quando avaliou-se a nodulação das raízes, atribuindo-se caráter positivo às amostras cujas plantas apresentaram ao menos um nódulo e, negativo, para aquelas que não apresentaram nódulos. Para a estimativa do número de células bacterianas nodulantes utilizou-se a tabela de número mais provável (Andrade e Hamakawa 1994) para a obtenção do fator NMP. O número final de células bacterianas nodulantes foi obtido pela média das três repetiçóes para cada amostra de solo, realizando também a correção em relação à umidade do solo.

A comparação das densidades médias de rizóbio entre as áreas foi realizada através de análise de variância e teste $\mathrm{t}$ a $5 \%$ de probabilidade, em cada período de avaliaçáo para cada cultura e, também, na média geral dos períodos. Quando necessário foram realizadas transformação dos dados (log de $\mathrm{x}+1)$ para o atendimento das pressuposiçóes da análise.

Para avaliar a flutuação da densidade de rizóbio ao longo do período de estudo, foi realizada uma análise de variância a 5\% de probabilidade com os dados de cada uma das áreas, totalizando assim três análises, considerando o delineamento em blocos casualizados, com três repetiçôes, em esquema fatorial $5 \times 2$, correspondendo às cinco épocas de coleta dos dados $(0,45,90,135$ e 180 dias) e as duas espécies isca (soja e feijão-caupi). A partir destas análises foram verificados ajustes de modelos de regressão aos dados para o fator época para cada espécie isca.

\section{RESULTADOS E DISCUSSÃO}

Constatou-se com as análises física e química do solo que todas as áreas estudadas apresentavam solo arenoso e baixo teor de matéria orgânica e de potássio (Tabela 1), que são características naturais dos solos dos cerrados de Roraima (Benedetti et al. 2011). Entretanto, em decorrência da correção e adubação durante o preparo do solo, as áreas cultivadas apresentaram teores mais elevados de $\mathrm{Ca}, \mathrm{Mg}$ e $\mathrm{P}$, comparativamente com a área de referência, não havendo diferenças expressivas entre elas (Tabela 1).

Durante o período deste estudo houve precipitação pluvial decrescente desde setembro de 2006 até o final de fevereiro de 2007 (Tabela 2). Além disso, foram observadas irregularidades na distribuição das chuvas dentro de cada mês e, praticamente, ausência por mais de 90 dias, a partir da última semana de novembro até o final de fevereiro de 2007. Este regime de chuvas no período de estudo foi semelhante à série histórica registrada para esta área de cerrado desde o ano de 1994, quando as mediçóes foram iniciadas (Mourão et al. 2006).

Tabela 1 - Análise da fertilidade e textura do solo no Campo Experimental Água Boa da Embrapa Roraima, Município de Boa Vista-RR.

\begin{tabular}{|c|c|c|c|c|c|c|c|c|c|c|}
\hline \multirow{3}{*}{ Áreas } & \multirow{2}{*}{$\mathrm{pH}$} & \multirow{2}{*}{ Al } & \multirow{2}{*}{ K } & \multirow{2}{*}{$\mathrm{Ca}$} & \multirow{2}{*}{$\mathrm{Mg}$} & \multirow{2}{*}{ M.0. } & \multirow{2}{*}{$P$} & \multicolumn{3}{|c|}{ Textura $^{1}$} \\
\hline & & & & & & & & Areia & Silte & Argila \\
\hline & $\mathrm{H}_{2} \mathrm{O}$ & & $\mathrm{cmol}$ & $\mathrm{dm}^{-3}$ & & $\mathrm{~g} \mathrm{dm}^{-3}$ & $\mathrm{mg} \mathrm{dm}^{-3}$ & & $\mathrm{~g} \mathrm{~kg}^{-1}$ & \\
\hline Referência & 3,8 & 0,4 & 0,00 & 0,1 & 0,03 & 10,1 & 0,3 & & & \\
\hline $1^{\circ}$ cultivo & 5,4 & 0,0 & 0,03 & 0,9 & 0,30 & 10,8 & 26,2 & 840 & 10 & 150 \\
\hline $2^{\circ}$ cultivo & 5,6 & 0,0 & 0,05 & 1,1 & 0,27 & 11,7 & 30,1 & & & \\
\hline
\end{tabular}

1Textura do solo classificada como franca-arenosa de acordo com o Sistema Brasileiro de Classificação do Solo (Embrapa, 2006).

$1^{\circ}$ cultivo - área com um cultivo de soja. $2^{\circ}$ cultivo - área com dois cultivos de soja. M. 0. - matéria orgânica 
Tabela 2 - Média da precipitação pluvial semanal durante o período de setembro de 2006 a março de 2007 em área de cerrado no Campo Experimental Água Boa da Embrapa Roraima, Município de Boa Vista-RR.

\begin{tabular}{|c|c|c|c|c|c|c|c|c|}
\hline \multirow{3}{*}{ Semana } & \multicolumn{8}{|c|}{ Precipitação pluvial (mm) ${ }^{1}$} \\
\hline & \multicolumn{5}{|c|}{ 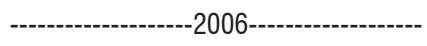 } & \multicolumn{3}{|c|}{--------2007---------- } \\
\hline & Ago & Set & Out & Nov & Dez & Jan & Fev & Mar \\
\hline $1^{\mathrm{a}}$ & 20 & 28 & 0 & 52 & 2 & 0 & 0 & 41 \\
\hline $2^{\mathrm{a}}$ & 63 & 12 & 7 & 8 & 0 & 0 & 0 & 0 \\
\hline $3^{\mathrm{a}}$ & 23 & 0 & 54 & 31 & 0 & 0 & 0 & 0 \\
\hline $4^{\mathrm{a}}$ & 90 & 45 & 19 & 0 & 0 & 3 & 0 & 120 \\
\hline Total & 195 & 85 & 81 & 91 & 2 & 3 & 0 & 161 \\
\hline
\end{tabular}

${ }^{1}$ Coletas realizadas diariamente utilizando-se pluviômetro de campo.

De forma geral, na área de referência foi observado baixo número de bactérias nodulantes, cerca de 10 células por grama de solo na média geral das duas espécies isca sendo inferior às médias das áreas com um e dois cultivos de soja, as quais apresentaram valores de $1,94 \times 10^{3}$ a $11,3 \times 10^{3}$ células $\mathrm{g}^{-1}$ solo, respectivamente. Além disso, na área de referência ocorreram diferenças entre as duas espécies isca, isto é, praticamente não foi observada nodulação em soja, enquanto que para o feijãocaupi detectou-se a presença de rizóbios em todas as coletas, que variou de algumas dezenas a até centenas de células por grama de solo (Tabela 3).

Estes dados corroboram informaçóes anteriores que indicaram que a soja praticamente não estabelece nodulaçẫo

Tabela 3 - População de rizóbio no solo durante o período de setembro de 2006 a março de 2007 em área de cerrado no Campo Experimental Água Boa da Embrapa Roraima, Município de Boa Vista-RR1.

\begin{tabular}{|c|c|c|c|c|c|c|c|c|}
\hline \multirow{2}{*}{$\begin{array}{l}\text { Período } \\
\text { (dias) }\end{array}$} & \multicolumn{2}{|c|}{$\begin{array}{l}\text { Área de } \\
\text { referência }\end{array}$} & \multicolumn{2}{|c|}{$\begin{array}{l}\text { Área de } 1^{\circ} \\
\text { cultivo }\end{array}$} & \multicolumn{2}{|c|}{$\begin{array}{l}\text { Área de } 2^{\circ} \\
\text { cultivo }\end{array}$} & $\begin{array}{c}\text { Probabilidade } \\
\text { Exata }\end{array}$ & $\begin{array}{l}\text { CV } \\
(\%)\end{array}$ \\
\hline & \multicolumn{8}{|c|}{ Número de rizóbio (Células g-1 de solo) } \\
\hline \multicolumn{9}{|c|}{ Soja como planta hospedeira } \\
\hline 0 & 0 & C & 3430 & B & 64330 & A & 0,0000 & 2,5 \\
\hline 45 & 14 & C & 330 & B & 4100 & A & 0,0015 & 25,1 \\
\hline 90 & 0 & C & 430 & B & 3670 & A & 0,0000 & 3,9 \\
\hline 135 & 0 & C & 150 & B & 1100 & A & 0,0000 & 3,6 \\
\hline 180 & 7 & B & 50 & B & 290 & A & 0,0046 & 29,5 \\
\hline Média & 4 & C & 880 & B & 14700 & A & 0,0000 & 11,7 \\
\hline \multicolumn{9}{|c|}{ Feijão-caupi como planta hospedeira } \\
\hline 0 & 10 & C & 13800 & $A B$ & 29670 & A & 0,0112 & 54,9 \\
\hline 45 & 597 & B & 520 & B & 3970 & A & 0,0119 & 9,6 \\
\hline 90 & 223 & B & 300 & B & 2970 & A & 0,0000 & 4,6 \\
\hline 135 & 130 & C & 210 & B & 2700 & A & 0,0000 & 2,5 \\
\hline 180 & 11 & B & 120 & B & 380 & A & 0,0014 & 39,3 \\
\hline Média & 1940 & B & 2990 & B & 7940 & A & 0,0020 & 40,2 \\
\hline
\end{tabular}

'Médias seguidas de mesmas letras na linha, não diferem entre si pelo teste t. Área de $1^{\circ}$ cultivo - área com um cultivo de soja. Área de $2^{\circ}$ cultivo - área com dois cultivos de soja. com bactérias nativas de solos brasileiros e, ao contrário, o feijão-caupi, apresenta ampla capacidade de nodulaçáo com estas bactérias (Hungria et al. 2005; Zilli et al. 2009). Esta capacidade do feijáo-caupi nodular com bactérias nativas de solos brasileiros já foi demonstrada em diferentes regiôes incluindo Mata Atlântica, Cerrado, Amazônia e Semiárido (Martins et al. 2003; Zilli et al. 2004; Lima et al; 2005; Chagas Júnior et al. 2009).

Considerando a soja como planta isca, observou-se que o cultivo com essa leguminosa ocasionou maior densidade de rizóbio em todos os períodos de avaliação, sendo o valor na área referência menor do que o das demais áreas e o da área de $1^{\circ}$ cultivo maior que a área de referência, porém menor do que o da área de $2^{\circ}$ cultivo (Tabela 3 ). Isto indica que o cultivo da soja a partir de sementes inoculadas promoveu, de forma geral, aumento na densidade de rizóbio no solo e, esta densidade foi elevada com o aumento do número de cultivos.

Por outro lado, considerando o feijáo-caupi como espécie isca foi observado diferenças significativas entre a área de referência e a de $1^{\circ}$ cultivo apenas na primeira e terceira avaliaçấo, enquanto que nas duas áreas cultivadas ocorreram diferenças significativas em todas as coletas a exceção da primeira (Tabela 3). Isto mostra que mesmo em área nativa existe uma população de rizóbios estabelecida capaz de nodular o feijão-caupi e que o cultivo da soja tende a aumentar esta população, entretanto, em proporçóes menores do que as observadas para a soja.

O cultivo sucessivo de uma leguminosa em uma mesma área tende a elevar a densidade de bactérias nodulantes no solo, isto porque a multiplicação dos rizóbios é favorecida com a nodulação das plantas e estes nódulos representam uma proteçáo contra as adversidades edafoclimáticas (Ferreira et al. 2000; Hungria e Vargas 2000). Ferreira et al. (2000), em estudo conduzido no Paraná em sistema de plantio direto e convencional em rotação e sucessão de culturas, observaram que o cultivo da soja em sucessão com trigo (Triticum aestivum) ou milho (Zea mays), mesmo sem a inoculação de sementes durante um período de 15 anos, proporcionou aumento da populaçấo de bactérias nodulantes da ordem de $10^{2}$ para $10^{3}$, comparativamente a uma área sem o cultivo de leguminosas. Além disso, também observaram que não apenas a densidade de Bradyrhizobium, mas também a diversidade genética destas bactérias aumentou na área com cultivo de soja (Ferreira et al. 2000).

No Brasil, a introdução da soja nos solos de cerrado da regiáo central constitui exemplo de que a presença da leguminosa proporciona alteraçáo na estrutura da comunidade de bactérias nodulantes no solo (Mendes et al. 2004; Hungria et al. 2005). Segundo estes autores, quando da introdução da soja nas décadas de 60 e 70 do século passado, os solos desta região praticamente não possuíam bactérias nodulantes de soja 
e, portanto, recomendava-se o uso de algumas estirpes exóticas, incluindo a CB1809, a 532C e a SEMIA 5020. Passados 15 a 20 anos, entretanto, estes solos passaram a apresentar alta diversidade de Bradyrhizobium nodulantes de soja com estirpes com perfis de proteínas semelhantes às estirpes originais, mas apresentando diferenças genéticas e de eficiência na FBN marcantes (Galli-Terasawa et al. 2003; Mendes et al. 2004).

Com relação ao número de rizóbios ao longo do período dos 180 dias do estudo náo foi observada uma tendência definida de flutuação da população na área de referência. Para a soja, como mencionado anteriormente, ocorreu nodulação apenas esporádica e, para o feijão-caupi, em termos absolutos ora observou-se população mais elevada, ora mais baixa, mas sem identificação de possíveis fatores que estivessem influenciando esta população. Provavelmente, o principal fator envolvido na manutenção desta população seja a presença de leguminosas nativas, que são abundantes nestas áreas de cerrado (Flores e Rodrigues 2010).

Para as áreas cultivadas, embora no primeiro período existisse uma média até acima de $60 \times 10^{3}$ rizóbios por grama de solo no caso da soja e, que o aumento do número de cultivos de soja tenha elevado este número (Tabela 3), nos períodos subsequentes a média ficou entre uma dezena e uma centena de rizóbios por grama de solo na área de $1^{\circ}$ cultivo (Figura 1 e 2) e entre uma centena a alguns milhares na área de $2^{\circ}$ cultivo (Figura 1 e 2 ). Também observou-se que a flutuação da população de rizóbio para ambas espécies isca foi semelhante, assim como a proporção de redução em ambas as áreas cultivadas (Figura 1 e 2). Além disso, foi possível constatar que a densidade de rizóbios no solo sofreu uma intensa redução (na média mais de $90 \%$ em teremos absolutos) nos primeiros 45 dias do estudo e, considerando

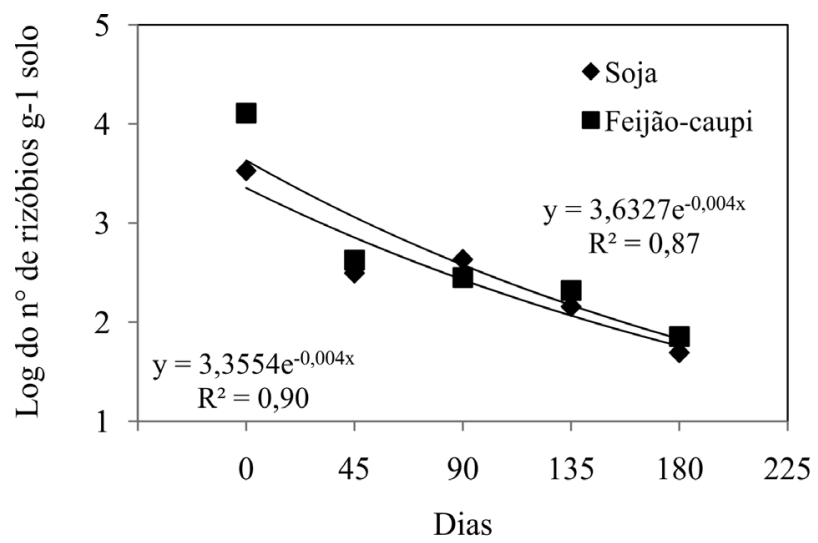

Figura 1 - Flutuação da população de rizóbio no solo durante 0 período de setembro de 2006 a março de 2007 em área de cerrado no Campo Experimental Água Boa da Embrapa Roraima, Município de Boa Vista-RR em área de primeiro cultivo de soja. (•) Soja e (๘) feijão-caupi como espécies isca. Os pontos nas figuras indicam o log das médias originais com três repetições. Nível de significância $\leq 0,05$. o inicio e final do estudo a redução desta densidade chega a superar $99 \%$ da população inicial.

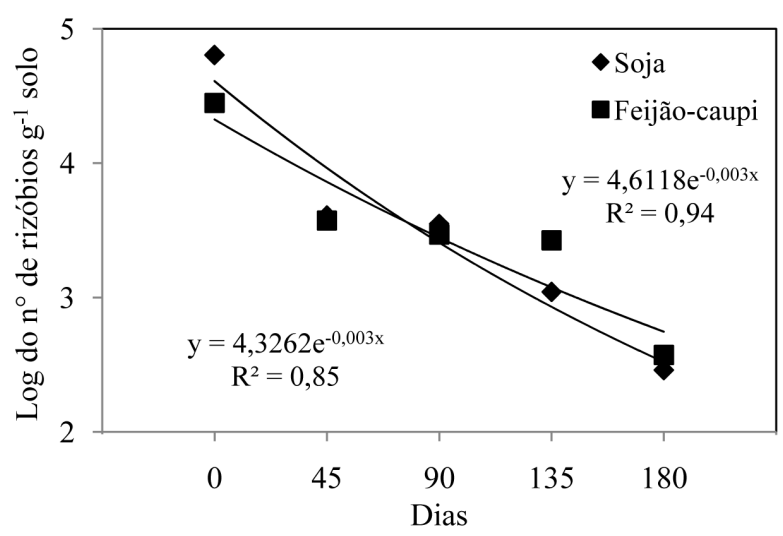

Figura 2 - Flutuação da população de rizóbio no solo durante 0 período de setembro de 2006 a março de 2007 em área de cerrado no Campo Experimental Água Boa da Embrapa Roraima, Município de Boa Vista-RR em área de segundo cultivo de soja. $(\bullet)$ Soja e (ロ) feijão-caupi como espécies isca. Os pontos nas figuras indicam o log das médias originais com três repetições. Nível de significância $\leq 0,05$.

No período inicial ocorreram chuvas moderadas, com boa distribuiçẫo e acúmulo de mais de $120 \mathrm{~mm}$ e (Tabela 2) e que, portanto, aparentemente ainda não configuraria uma escassez de água no solo que afetasse grandemente as bactérias do solo. Por outro lado, devido à primeira coleta de solo ter sido realizada logo após a colheita da soja, a ausência da cultura tornou-se um fator importante capaz de justificar a intensa redução da densidade de rizóbios no solo do primeiro para o segundo período de amostragem. Posteriormente, entretanto, no mês de novembro, as chuvas se tornaram escassas, passando a ser o fator mais marcante na redução da população de rizóbios no solo, que variou de alguns milhares a uma centena de células $\mathrm{g}^{-1}$ solo durante cada período, respectivamente na média da área de $1^{\circ}$ cultivo e na área de $2^{\circ}$ cultivo (Figura 1 e 2 ).

É sabido que tanto a presença da leguminosa quanto a disponibilidade de água afetam a sobrevivência de rizóbios no solo (Hungria e Vargas 2000) e, portanto a colheita da cultura da soja e a escassez de chuvas no período do estudo certamente influenciaram na densidade de rizóbios no solo do cerrado de Roraima. Neste caso, a retirada da cultura reduziria grandemente a população de rizóbio logo nas primeiras semanas após a colheita e, a escassez de chuvas continuaria a reduzir esta populaçáo durante os meses de estiagem subsequentes.

No caso específico da soja, observou-se que, após a estiagem, restaram no solo cerca de 50 e 200 células de rizóbio $\mathrm{g}^{-1}$ solo, respectivamente na área de $1^{\circ}$ e $2^{\circ}$ cultivos. Pesquisas realizadas nas décadas passadas evidenciaram que 
uma concentração entre 100 a 1000 células de rizóbio $\mathrm{g}^{-1}$ de solo teoricamente garantiriam uma adequada nodulação das plantas e o processo de FBN em diversas leguminosas (Herridge 2008). Entretanto, em experimentos conduzidos nas principais regióes produtoras de soja do Brasil constatou-se que em áreas com plantio de soja inoculada por várias safras, há o estabelecimento de uma populaçáo nodulante da ordem de $10^{3}$ a até $10^{6}$ células $\mathrm{g}^{-1}$ solo e, mesmo com esta alta população de bactérias nesses solos, foram observados incrementos de produtividade de grãos de até $15 \%$ pela re-inoculação da semente de soja anualmente (Hungria et al. 2007).

Desta forma, este trabalho demonstra que, em solos do cerrado, a estiagem provoca grande redução na densidade rizóbio e, mesmo que o cultivo da soja ao longo das safras tenda a elevar esta população, a inoculação da soja é necessária, haja vista que a população de bactérias no solo seria insuficiente para garantir uma boa nodulaçáo e, portanto, os riscos de insucesso na lavoura seriam evidentes.

\section{CONCLUSÕES}

O número de cultivos de soja inoculada eleva a densidade de rizóbios no solo do cerrado de Roraima;

Durante o período de estiagem no cerrado de Roraima ocorre uma drástica redução na densidade de rizóbios no solo, que pode superar $99 \%$, considerando a população no início e final do período.

\section{BIBLIOGRAFIA CITADA}

Andrade, D.S.; Hamakawa, P.J. 1994. Estimativa do número de células viáveis de rizóbio no solo e em inoculantes por infecção em plantas, p.63-94. In: Hungria, M.; Araújo, R.S. (Eds). Manual de métodos empregados em estudos de microbiologia agrícola. Embrapa-SPI, Brasília, Distrito Federal.

Barbosa, R.I. Homem, ambiente e ecologia no Estado de Roraima, p.325-335. In: Barbosa, R.I.; Ferreira, E.J.; Castellón, E.G. (Eds). Homem, ambiente e ecologia no Estado de Roraima. INPA, Manaus, Amazonas.

Benedetti, U.G.; Vale Júnior, J. F.; Schaefer, C.E. G.R.; Melo, V.F.; Uchôa, S.C.P. 2011. Gênese, química e mineralogia de solos derivados de sedimentos pliopleistocênicos e de rochas vulcânicas básicas em Roraima, Norte Amazônico. Revista Brasileira de Ciência do Solo, 35: 299-312.

Chagas Junior, A.F.; Oliveira, L.A.; Oliveira, A.N.; Willerding, A.L. 2009. Efetividade de rizóbios e caracterização fenotípica dos isolados que nodulam feijão-caupi em solos da Amazônia Central. Acta Amazonica, 39: 489-494.

Chalk, P.M.; Alves, B.J.R.; Boddey, R.M.; Urquiaga, S. 2010. Integrated effects of abiotic stresses on inoculant performance, legume growth and symbiotic dependence estimated by ${ }^{15} \mathrm{~N}$ dilution. Plant and Soil, 328:1-16.
Empresa Brasileira de Pesquisa Agropecuária - EMBRAPA. Centro Nacional de Pesquisa de Solos. Sistema Brasileiro de Classificação de Solos. 2 ed. Rio de Janeiro, 2006. 306p.

Ferreira, M.C.S.; Andrade, D.O.; Chueire, L.M.; Takemura, S.M.; Hungria, M. 2000. Tillage method and crop rotation effects on the population sizes and diversity of bradyrhizobia nodulating soybean. Soil Biology and Biochemistry, 32: 627-637.

Figueiredo, M.V.B.; Vilar, J.J.; Burity, H.A.; França, F.P. 1999. Alleviation of water stress effects in cowpea by Bradyrhizobium spp. inoculation. Plant and Soil, 207: 67-75.

Flores, A. S.; Rodrigues, R. S. 2010. Diversidade de leguminosae em uma área de savana do estado de Roraima, Brasil. Acta Botanica Brasilica, 24:175-183.

Galli-Terasawa, L.V.; Glienke-Blanco, C.; Hungria, M. 2003. Diversity of a soybean rhizobial population adapted to a Cerrados soil. World Journal of Microbiology and Biotechnology, 19: 933-939.

Herridge, D.F. 2008. Inoculation technology for legumes, p. 77-115. In: Dilworth, M.J.; James, E.K.; Sprent, J.I.; Newton, W.E. (Eds.). Nitrogen-fixing Leguminous Symbioses. v. 7. Springer, Dordrecht, Netherlands.

Hungria, M.; Campo, R.J.; Mendes, I.C. 2007. A importância do processo de fixação biológica do nitrogênio para a cultura da soja: componente essencial para a competitividade do produto brasileiro. Documentos, 283. Embrapa Soja, Londrina, Paraná. 80pp.

Hungria, M.; Franchini, J.; Campo, R.; Graham, P. 2005. The importance of nitrogen fixation to soybean cropping in South America, p. 25-42. In: Werner, D.; Newton, W. (Eds.). Nitrogen Fixation in Agriculture, Forestry, Ecology, and the Environment. v.4. Springer, Dordrecht, Netherlands.

Hungria, M.; Vargas, M.A.T. 2000. Environmental factors affecting $\mathrm{N}_{2}$ fixation in grain legumes in the tropics, with an emphasis on Brazil. Field Crops Research, 65: 151-164.

Lima, A.S.; Pereira, J.P.A.R.; Moreira, F.M.S. 2005. Diversidade fenotípica e eficiência simbiótica de estirpes de Bradyrhizobium spp. de solos da Amazônia. Pesquisa Agropecuária Brasileira, 40: 1095-1104.

Martins, L.M.V.; Xavier, G.R.; Rangel, F.W.; Ribeiro, J.R.A.; Neves, M.C.P.; Morgado, L.B.; Rumjanek, N.G. 2003. Contribution of biological nitrogen fixation to cowpea: a strategy for improving grain yield in the semi-arid region of Brazil. Biology and Fertility of Soils, 38: 333-339.

Mendes, I.; Hungria, M.; Vargas, M. 2004. Establishment of Bradyrhizobium japonicum and B. elkanii strains in a Brazilian Cerrado oxisol. Biology and Fertility of Soils, 40: 28-35.

Mourão Junior, M.; Moura Neto, M.A.; Bendahan, A.B.; Xaud, M.R.; Xaud, H.A.M. 2006. Probabilidade de precipitação pluvial mensal no campo experimental Água Boa, Boa Vista - Roraima (1991-2005). Boletim de Pesquisa e Desenvolvimento, 08. Embrapa Roraima, Boa Vista, Roraima. 18 pp. 
Sadowsky, M. 2005. Soil stress factors influencing symbiotic nitrogen fixation, p. 89-112. In: Werner, D.; Newton, W. (Eds.). Nitrogen Fixation in Agriculture, Forestry, Ecology, and the Environment.v. 4. Springer, Dordrecht, Netherlands.

Serraj, R.; Sinclair, T.R. 1998. Soybean cultivar variability for nodule formation and growth under drought. Plant and Soil, 202: 159-166.

Streeter, J.G. 2003. Effects of drought on nitrogen fixation in soybean root nodules. Plant, Cell and Environment, 26: 1199-1204.

Waldon, H. B.; Jenkins, M. B.; Virginia, R.A.; Harding, E.E. 1989. Characteristics of woodland rhizobial populations from surface and deep soil environment of the Sonoran Desert. Applied and Environmental Microbiology, 55: 3058-3064.
Zahran, H.H. 1999. Rhizobium-legume symbiosis and nitrogen fixation under severe conditions and in an arid climate. Microbiology and Molecular Biology Reviews, 63: 968-989.

Zilli, J.E.; Valisheski, R.R.; Freire Filho, F.R.; Neves, M.C.P.; Rumjanek, N.G. 2004. Assessment of cowpea rhizobium diversity in Cerrado areas of northeastern Brazil. Brazilian Journal of Microbiology, 35: 281-287.

Zilli, J.E.; Vilarinho, A.A.; Alves, J.M.A. 2009. A cultura do feijāocaupi na Amazônia brasileira: Embrapa Roraima, Boa Vista, Roraima. 356 pp.

Recebido em: 24/01/2012

Aceito em:05/06/2012 